International Journal of Advanced Academic Research (Sciences, Technology and Engineering) | ISSN: 2488-9849 Vol. 6, Issue 7 (July, 2020)| www.ijaar.org

Journal DOI: 10.46654/ij.24889849

Article DOI: 10.46654/ij.24889849.e671

\title{
A COMPARATIVE STUDY OF THE PERFORMANCE OF SPENT MUSHROOM SUBSTRATE AND INDUSTRIAL FERTILIZER IN GROWING SOLANUM LYCOPERSICUM L. VAR. REMOTA
}

\author{
F.W. Nmom ${ }^{1}$, C.W. Worlu ${ }^{1}$ and M.G. Ajuru ${ }^{1^{*}}$ \\ ${ }^{1}$ Department of Plant Science and Biotechnology, Faculty of Science, Rivers State University, \\ Nkpolu-Oroworukwo, P. M. B. 5080, Port Harcourt, Rivers State, Nigeria. \\ *Corresponding Author: \\ Email: ajurumercygospel@yahoo.com \\ Phone no: +2347036834588
}

\begin{abstract}
Due to the claim that some varieties of Solanum lycopersicum (Tomato) do not thrive in Southern Niger Delta of Nigeria, there has been elaborate use of chemical fertilizers in order to sustain the supply of this plant. It has been reported that chemical fertilizer are not eco-friendly, expensive and contains toxic substance. Therefore, there is a desire for an eco-friendly fertilizer for organic food production. This work was carried out to compare the performance of S. lycopersicum on spent mushroom substrate (SMS) and chemical fertilizer. A multi-sampling method was used to grow the test crop in both rainy (May-October) and dry (November-April) seasons, using fresh and weathered spent substrates and also Nitrogen - PhosphorousPotassium fertilizer (NPK). Results implicated that spent mushroom substrate potted soil was the best for nursery trials at $p \leq 0.05$ degree of judgement. The weathered spent mushroom substrate was profitable more than the chemical fertilizer. Using top-dressing with the weathered substrate was significant in both seasons $(F=43.4, d f=1 ; P \leq 0.05)$. The results showed that some varieties of S. lycopersicum can thrive suitably in Southern Niger Delta of Nigeria if the spent mushroom substrate is applied to the soil as organic fertilizer.
\end{abstract}

Keywords: Spent mushroom substrate, Solanum lycopersicum, Chemical fertilizer, Niger Delta Region, Solanaceae. 


\section{Introduction}

Mushroom growing is an eco-friendly activity, usually cultivated on composted or non composted substrates, prepared for their growth. Plants' wastes are the basal materials utilized for cultivation of edible mushrooms. The substrates could be supplemented with nutrients such as wheat, or rice brans, cassava peels, soya beans, lime and gypsum as fertilizer. This mixture is formulated and pasteurized under controlled conditions (Ahlawat and Sagar, 2007; Fasidi et al., 2008; Nmom and Elenwo, 2012). The inoculation of the substrates with mushroom mycelia is fundamental and the environmental conditions in the growth, manipulated to encourage mushroom mycelia growth and production of mushroom (Beyer, 1999; Speranzini, 2007).

After several harvest or flushes of the mushroom, the substrates get exhausted or spent of its potential to produce more mushrooms and are dislodged as spent mushroom substrate. Mushrooms industry needs to dispose off used substrates for subsequent produce (Fox and Chonver, 1999). The dislodged used substrate or compost is referred to as "spent mushroom substrate or compost (synonym post mushroom substrate).

Spent mushroom substrate (SMS) is the organic material on which mushroom grew for a period of several weeks and are removed after mushroom production is completed. It can also be described as the left-over materials on which mushrooms are grown within mushroom house as a by-product of the mushroom industry (Davis and Kuhns, 2005). The soil-like materials which remain after a crop of mushroom. Spent substrate could be "fresh"; if disposed immediately from the mushroom house after mushroom production, or "weathered"; if allowed for several weeks or months to decompost (Djaja et al., 2003; Priadi and Saskiawan, 2008). However, both types must be free from ammonium, rotten egg or sulphur smell and must possess earthy odour before it can be considered efficient for use to grow crops like vegetables, fruits and cereals etc. (Beyer, 1999; Speranzini, 2007; Priadi and Saskiawan, 2008).

It is the search for the eco-friendly organic plant-based fertilizers with organic residues that has increased the demand for SMS as against the elaborate use of field inventories which is hazardous to plant, man and the ecosystem. The chemical fertilizer has its chemical residues retained in the tissues of plant and its products such as fruits. The cultivation of mushrooms on different substrates increases the crude protein, fibre and ash contents of SMS in addition to enhancing the digestibility of crude proteins by plants (Zhang et al., 1995).

The most valuable aspect of SMS is its high organic matter; which allows soil to retain moist in dry weather and shed it during wet weather. Spent substrate acts as a sponge in gravel or sandy soils and creates air spaces in clay soils, permitting them to drain. Spent substrate will not leach from the ground. If applied correctly, nutrients remain in soil and do not contribute to ground water pollution, unlike chemical fertilizers. It has many advantages over other compost produced from chemicals, food and garden wastes (Djaja et al., 2003; Gumus and Seker, 2007; Wuest et al., 1995; Beyer, 1996; Romaine and Holcomb, 2001). Spent mushroom substrate is a consistent, formular and homogenous product, cycled through the year with consistent materials and composite products.

Spent substrate is utilized as bio-fertilizer or soil conditioner; its application is a way to improve soil physico-chemical properties; with 40-44\% cellulose; 20-32\% hemicelluloses and 25-35\% lignin, if sawdust is a basal nutrient (Ahlawat and Sagar, 2007; Haygreen and Bowyer, 1989). The product is weed free in nature due to extensive composting and pasteurization which prevent weed seed to enter the product. It has no nitrogen draw-down problems and reduces 
consumer concerns about heavy metals. It supports plant growth and creates a propagative medium. In using SMS, an ideal moisture content of 30\%, pH 6 is considered important (Mahar, 1991).

It is also a known fact that chemical fertilizer supports the growth of plants by enhancing the nutrients; however, it has been reported that chemical fertilizer are expensive; contains toxic substance. They are hazardous to skin, respiratory tract; can build up in the soil and cause long term imbalance in soil $\mathrm{pH}$ and fertility (Pakinson and Quarnby, 2000). Field inventory causes pollution of water ways; increases air pollution, acidifies the soil and can lead to depletion of the soil (Fox and Chonver, 1999; Dann, 1996; Grabbe, 1982). The SMS for this study was obtained from the cultivation of Lentinus squarrosulus, a white rot fungus.

Solanum lycopersicum is a vegetable crop that belongs to the family Solanaceae. It is commonly known as tomato plant originated from Central and South America and now, worldwide for its edible fruits, grown as annual plant in all regions. Its usage is enormous.

Considering the importance of tomato as a food crop and the valuable nutrients in both organic and inorganic fertilizers in raising it, this study therefore aimed at comparing the performance of organic (SMS) and inorganic (NPK) fertilizers in growing Solanum lycopersicum and the subsequent recommendation of the most profitable to small scale farmers.

\section{Materials and Methods}

The sporophores of L. squarrosulus was derived from tissue culture of the cultivated mushroom procured from the natural habitat of logs of Mangifera indica L. collected from various locations of Ndele campus of the Ignatius Ajuru University of Education, Rumuolumeni, Port Harcourt, Rivers State, Nigeria, where the study was carried out. The materials used for mushroom cultivation; saw dust, cassava peels, palm fibres were obtained from the communities around the Ndele Campus. The spent substrates were derived from the cultivated L. squarrosulus.

Spent substrate contains $40-60 \%$ of organic matter on dry weight basis, usually analyzed in the laboratory through loss on ignition and the remnant serves as the mineral matter.

\section{Mineral content analysis of samples used for the study}

The mineral content of the SMS and the soil samples used were determined using semi-micro kjeldahl and EDTA acid digesting complex. An aliquot of digest of the samples was taken each for determination of Nitrogen, phosphorous, Potassium, Carbon, Calcium, Iron, Zinc, Magnesium and Manganese. The digest was mixed with acid diluted to volume $(0.5 \mathrm{~g})$ and the solution aspirated into flame. Blank determinations were taken and subtractions were made where necessary.

\section{Preparation of tomato seed for planting}

Healthy tomato fruits were procured from Ahoada, Elele-Alimini, Rumuji, Choba and Ndele; all along the East-west of Port Harcourt linking other states of the Niger Delta of Nigeria. These were brought to the experimental chamber of the study; dissected with clean pen knife to extract the seed for viability test. The viable seeds were washed in cold water, drained and sun-dried at $27^{0} \mathrm{c}$ for 2 days before planting unto nursery bags. 


\section{Methods of application of SMS (nursery)}

Into each nursery bag $(26 \times 10 \mathrm{~cm}), 250 \mathrm{~g}$ SMS was filled and four seeds sown per bag.

\section{Spent mushroom substrate-soil blend:}

Each nursery bag contained 200g soil mixed with 50g SMS and four seeds sown per bag.

\section{Spent mushroom substrate incorporation into soil:}

Each nursery bag contained 150g soil, layered with 50g SMS and topped with 50g soil. The SMS was incorporated in-between the two soil levels. Four seeds were sown into each bag.

Control: Each nursery bag was filled with $250 \mathrm{~g}$ soil only and four seeds sown per bag.

\section{Method of application of SMS (field)}

\section{Ring method}

Three weeks old seedlings from the nursery were transplanted into ready tilled beds at an intra row spacing of $25 \mathrm{~cm}$. The SMS supplement of $30 \mathrm{~g}, 50 \mathrm{~g}$ and $100 \mathrm{~g}$ per bed were applied in a ring form around the seedlings at $5 \mathrm{~mm}$ away from the main roots.

\section{Top-dressing (surface application)}

Three weeks old seedlings were top-dressed with $30 \mathrm{~g}, 50 \mathrm{~g}$ and $100 \mathrm{~g}$ sms per bed at $25 \mathrm{~cm}$ within the rows. The SMS top-dressed seedlings were protected from excessive heat or quick run off by watering and covered with sun-dried grass mulch during the dry season. These were however removed after about 4days to avoid decay and consequent alteration of results.

\section{Substrate incorporation into soil}

A depth of $7 \mathrm{~cm}$ each was created, 50g SMS incorporated and layered with 50g soil. These were watered for 10 days in dry season, thereafter, 3 weeks old seedlings were transplanted into them.

\section{Substrate-soil blend}

In a ready tilled bed, $1 \mathrm{~kg}$ soil was scooped into a clean basin, mixed with $300 \mathrm{~g}$ SMS and plunged back to the bed. Three weeks old seedlings were transplanted.

Control: Tomato seedlings of 3 weeks old were transplanted from the nursery onto the beds of tilled soil with $0 \mathrm{~g}$ SMS. All the experiments were carried out same way in both rainy and dry seasons, using fresh and weathered SMS.

\section{Application of NPK fertilizer (Nursery)}

NPK - soil blend

A $250 \mathrm{~g}$ soil was mixed with $16.2 \mathrm{~g}$ NPK chemical fertilizer. The blend was used to fill 20 nursery bags $(26 \times 10 \mathrm{~cm})$. Into each bag were sown 4 viable tomato seeds. 


\section{NPK Incorporation into soil}

Twenty nursery bags were filled with $200 \mathrm{~g}$ soil and $16.2 \mathrm{~g}$ NPK incorporated and soil with 4 seeds sown.

\section{Method of application of NPK (Field)}

\section{Ring method}

Three weeks old tomato seedlings from the nursery were transplanted into already tilled and dressed beds at $25 \mathrm{~cm}$ distance from one another. The NPK was applied in ring form at $25 \mathrm{~cm}$ away from the roots.

\section{NPK-Soil blend}

From already tilled beds, $1 \mathrm{~kg}$ soil was scooped into clean basin and mixed with $16.2 \mathrm{~g}$ (match level) NPK fertilizers and plunged back to the bed. Then 3 weeks old seedlings were transplanted per stand.

Control: Three weeks old tomato seedlings were transplanted from the nursery onto the bed of tilled soil, but with Og NPK. These were watered daily mostly in dry season.

\section{Data analysis}

The statistical tools used to arrive at results were tables, and figures, Statistical analysis were done using descriptive (statistics), T-test, ANOVA and Scheffe's multiple comparism test.

\section{Results}

Several test trials in this study showed that the use of weathered spent mushroom substrate of $\underline{L}$. Squarrosulus by top dressing was profitable in growing the test tomato crop. Weathered SMS sustained the crop into 4 times fruiting and harvest before the plant senescence and died.

\section{SMS as organic fertilizer (Nursery)}

\section{SMS-pot soil}

The tomato seeds germinated on the $3^{\text {rd }}$ day at $100 \%$ showing good seedling vigour at the early nursery age of 1-3 weeks. In 7 days, an average height of $7.5 \mathrm{~cm}$ was attained. As the seedling aged (4 weeks) yellowing and senescence occurred.

\section{SMS - soil blend}

Germination occurred on the $4^{\text {th }}$ day at $100 \%$ too with good seedling vigour. Seedling height at 7 days was $5.8 \mathrm{~cm}$.

\section{SMS incorporation into nursery soil}

Germination took place on the $5^{\text {th }}$ day at $100 \%$ and good seedling vigour. Height of seedling on the $7^{\text {th }}$ day was $5.1 \mathrm{~cm}$. 


\section{Control (Nursery)}

Germination was on the $5^{\text {th }}$ day showing good seed emergence at $100 \%$ and seedling vigour. Average height on $7^{\text {th }}$ day was 5.3. The study revealed that seedling growth was luxurious, however germination was faster in SMS-pot soil (fig. 1).

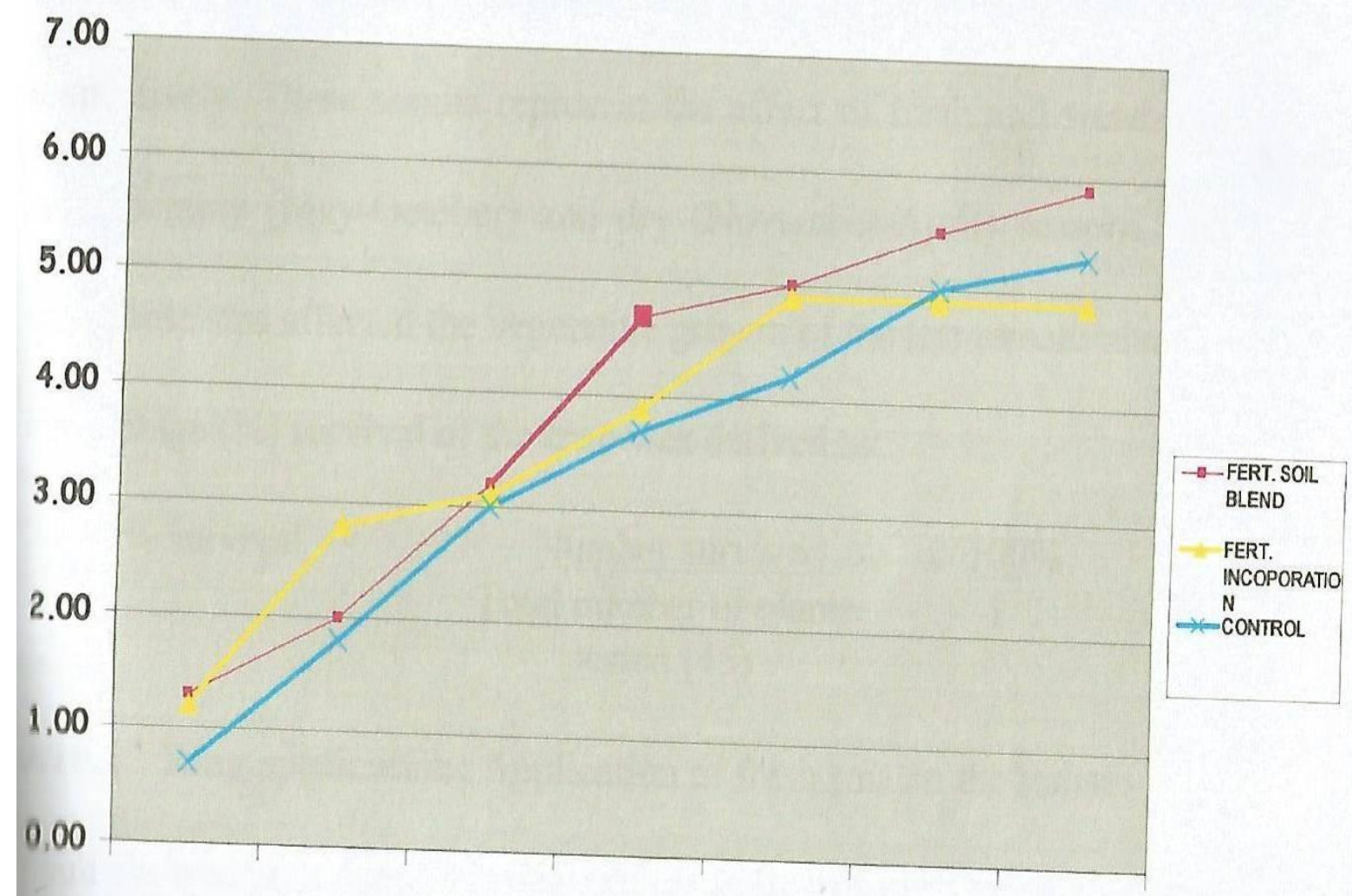

Fig1. A graph showing seedling vigour of tomato plant on SMS nursery application.

NPK application (Nursery): Tomato seeds germinated on the $5^{\text {th }}$ day from planting and occurred at $100 \%$. Seedling vigour was good enough at the early ages of 6-10 days. When the roots became extensive (14-16 days), vegetative growth slowed down and some withered and died at the depth of $90.5 \mathrm{~mm}(10.5 \mathrm{~cm})$ other near impaired ones were quickly transplanted to the field for resuscitation with weathered SMS in order to resume new vigorous life as reported earlier. On the $7^{\text {th }}$ day seedling height was only $5.9 \mathrm{~cm}$.

NPK incorporation into the soil: Germination was on the $5^{\text {th }}$ day too at $100 \%$. As the seedlings developed, and the roots spread down to reach the point of NPK incorporation, the roots were choked and degenerated leaving the seedlings dead, at ages 8-12 days. At the $7^{\text {th }}$ day, before the roots died, the seedling height was $4.9 \mathrm{~cm}$.

Control (NPK - Nursery): The seeds germinated on the $5^{\text {th }}$ day at $100 \%$. Seedling vigour was good, though sluggish. Average height on the $7^{\text {th }}$ day was $5.3 \mathrm{~cm}$ (Fig. 2). 


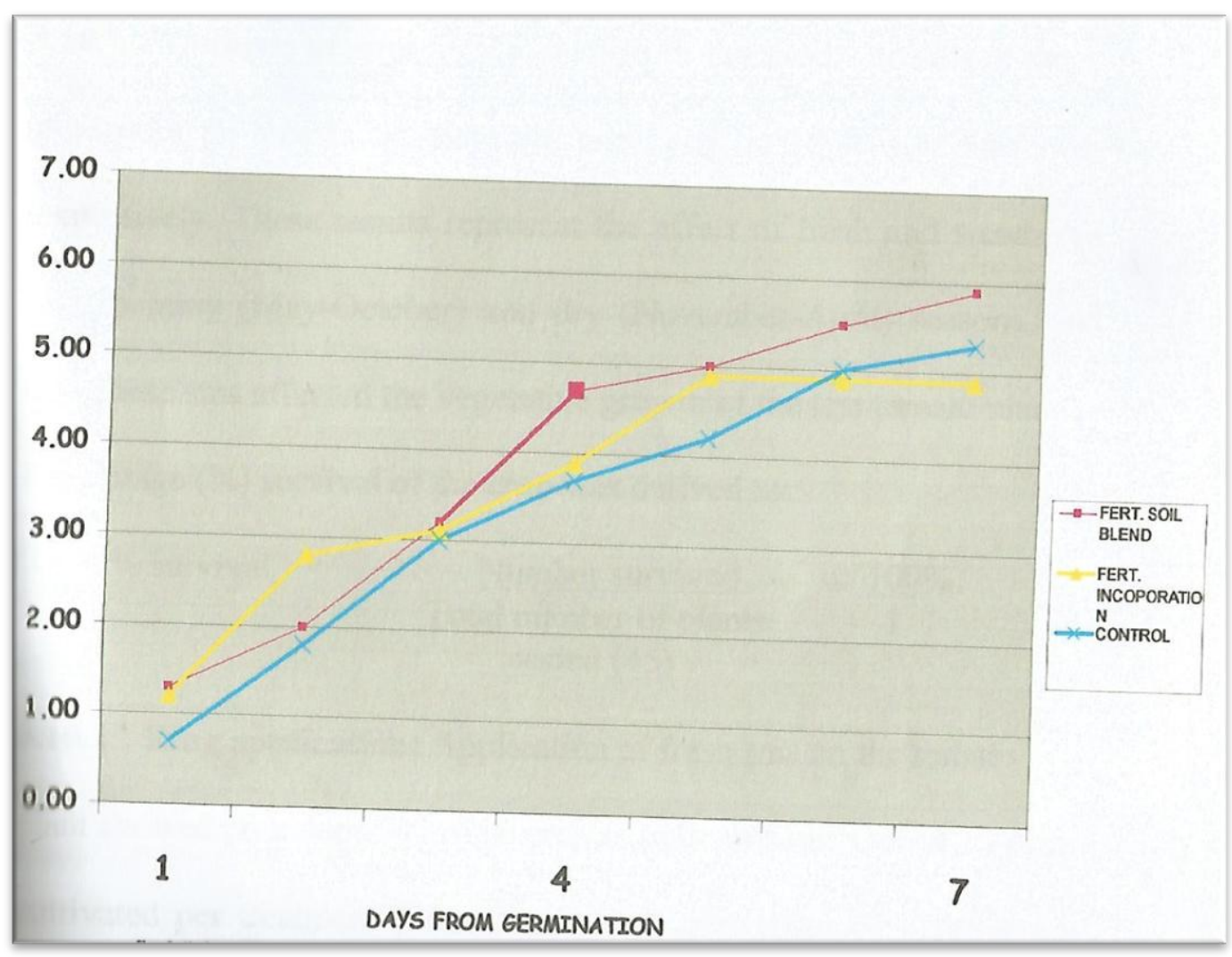

Fig2. A graph showing seedling vigour of tomato plant on NPK nursery application.

Application of SMS (field): The result represented the effect of fresh and weathered SMS in rainy (May-October) and dry (November-April) seasons and how these affected the vegetation growth of the test tomato plant.

Ring method application of SMS (field): The effect of fresh SMS resulted in poor vegetative growth during both seasons. Fresh SMS was harsh to the crop. A total of 33.2\% survived in the rainy season and $26.5 \%$ in the dry season. Application of weathered sms in the rainy season by ring method showed $46.6 \%$ survival and luxurious growth and $33.2 \%$ during the dry season.

Top-dressing (surface application) of sms in the field: By this treatment, fresh sms supported the survival of the tomato plant at $99.9 \%$ and $73 \%$ during the dry season. The $100 \mathrm{~g}$ concentration supported more vegetative growth in both seasons. Application of weathered sms by top-dressing was very efficient in both seasons. The total of $239 \%$ plant stands were sustained during the rains and $226 \%$ in the dry season from all the treatments (Table 1). 
Article DOI: 10.46654/ij.24889849.e671

Table 1. The mineral nutrients $(\%)$ of samples used in cropping tomato.

\begin{tabular}{|c|c|c|c|c|c|c|c|c|c|}
\hline Sample & & & & & & Mine & erals & & \\
\hline Identification & $\mathbf{N}$ & $\mathbf{P}$ & $\mathbf{K}$ & $\mathbf{N a}$ & Mg & $\mathrm{Ca}$ & $\mathbf{C}$ & Fe 2 & $\mathbf{Z n}$ \\
\hline Cultivated & & & & & & & & & \\
\hline L. subnudus & 4.97 & 5.718 & 73.546 & 14.69 & 45.80 & 0.734 & 1.97 & 0.27 & 0.105 \\
\hline Mixture of sm & as $0.07^{\mathrm{a}}$ & $0.107^{l}$ & $7^{\mathrm{b}} \quad 1.81$ & b $\quad 3.548^{\circ}$ & a 3.935 & $35^{\mathrm{a}} 2.764$ & $4^{\mathrm{c}} 9.36^{\mathrm{a}} 2.13$ & 3719.52 & $1.126^{\mathrm{a}}$ \\
\hline Soil sample & $0.084^{\mathrm{b}}$ & $16.84^{3}$ & 2.164 & $4^{\mathrm{b}} 2.205^{\mathrm{b}}$ & $4.809^{\mathrm{a}}$ & )$^{\mathrm{a}} 27.14^{\mathrm{a}}$ & $0.426^{\mathrm{c}} 21$. & $71^{\mathrm{a}} 31.45$ & 0.599 “ \\
\hline Mixture of & & & & & & & & & \\
\hline Sms + soil & $1.12^{\mathrm{a}}$ & $0.161^{\mathrm{b}}$ & $5.47^{\mathrm{a}}$ & $3.609^{\mathrm{a}}$ & $6.508^{\mathrm{b}}$ & $4.208^{b}$ & $3.24^{\mathrm{b}} 2.06$ & $2^{\mathrm{b}} 16.27^{\mathrm{b}}$ & ${ }^{\mathrm{b}} 0542^{\mathrm{a}}$ \\
\hline
\end{tabular}

Values with same letters in a column do not differ at 0.05 Alpha level.

Sms incorporation into the soil: This method was not good enough for the fresh samples of sms; however, it seemed to have thrived better only by the use of weathered sms (Table 2). 
Article DOI: 10.46654/ij.24889849.e671

Table 2. Percentage $(\%)$ survival of remota tomato treated with fresh SMS

\begin{tabular}{|c|c|c|c|c|c|c|c|}
\hline \multirow{2}{*}{$\begin{array}{l}\text { Type of } \\
\text { sms }\end{array}$} & \multirow[t]{2}{*}{ Season } & \multirow{2}{*}{$\begin{array}{l}\text { Method of } \\
\text { application }\end{array}$} & \multicolumn{4}{|c|}{ percentage $(\%)$ plant survival per treatment } & \multirow{2}{*}{$\begin{array}{l}\text { percentage }(\%) \text { plant } \\
\text { survival from all } \\
\text { treatment }\end{array}$} \\
\hline & & & $0 g$ & $30 \mathrm{~g}$ & $50 \mathrm{~g}$ & $100 \mathrm{~g}$ & \\
\hline & & Ring & 80 & 13.3 & 13.3 & 6.6 & $33.2^{\mathrm{d}}$ \\
\hline & & Top dressing & 80 & 33.3 & 33.3 & 33.3 & $99.9^{\mathrm{a}}$ \\
\hline & Rainy & Sms soil & & & & & \\
\hline & & Blend & 80 & 20 & 20 & 13.3 & $53.3^{c}$ \\
\hline \multirow[t]{5}{*}{ Fresh } & & Sms- inc. & 80 & 20 & 6.6 & 6.6 & $39.9^{c}$ \\
\hline & & Ring & 26.6 & 13.3 & 6.6 & 6.6 & $26.5^{\mathrm{d}}$ \\
\hline & & Top dressing & 80 & 33.3 & 33.3 & 33.3 & $99.9^{\mathrm{a}}$ \\
\hline & \multirow[t]{3}{*}{ Dry } & Sms soil & & & & & \\
\hline & & Blend & 26.6 & 6.6 & 0 & 0 & $6.6^{\mathrm{e}}$ \\
\hline & & Sms- inc. & 26.6 & 20 & 13.3 & 66 & $39.9^{c}$ \\
\hline
\end{tabular}

Value with same letters in column do not differ at 0.05 Alpha level

Control (sms-field): The plant survival with $0 \mathrm{~g}$ sms treatment gave rise to $80 \%$ plant survival in dry season. Those that could not stand the dried weather condition died. In the rainy season, the plant thrived with the normal $0 \mathrm{~g}$ sms soil (Table $2 \& 3$ ). 
Table 3. Percentage (\%) survival of remota tomato treated with weathered SMS

Type of sms Season $\quad$ Method of application percentage (\%) plant survival per percentage $(\%)$ treatment plant survival from all treatment

$\begin{array}{llllll} & 0 g & 30 g & 50 g & 100 g & \\ \text { Ring } & 80 & 20 & 13.3 & 13.3 & 46.6^{\mathrm{c}}\end{array}$

$\begin{array}{llllll}\text { Top dressing } & 80 & 66.6 & 80 & 93.3 & 239.9^{\mathrm{a}}\end{array}$

Rainy Sms soil

$\begin{array}{llllll}\text { Blend } & 80 & 13.3 & 13.3 & 6.6 & 32.2^{\mathrm{d}}\end{array}$

Weathered

$\begin{array}{lccccc}\text { Sms-inc. } & 80 & 46.6 & 33.3 & 20 & 99.9^{\mathrm{b}} \\ \text { Ring } & 22.6 & 13.3 & 13.3 & 6.6 & 32.2^{\mathrm{d}} \\ \text { Top dressing } & 22.6 & 60 & 80 & 86 & 226^{\mathrm{a}}\end{array}$

Value with same letters in column do not differ at 0.05 Alpha level

Field application of NPK: The result of this experiment is presented in Table 4 and indicated the effect of industrial fertilizer (NPK) on the vegetative development of the tomato plant. In the rainy season, ring method sustained $93.3 \%$ in a bed of 15 plant stands. The method of soil blending sustained $80 \%$ and the $0 \mathrm{~g}$ (control) sustained $86.6 \%$, soil blend $33.3 \%$.

In the dry season, the experiment was maintained with intensive care and tendering. Ring method sustained $66.6 \%$, soil blend, $33.3 \%$, and $26.6 \%$ from $0 \mathrm{~g}$ fertilizer (control) (Table 4). It is important to note that withering of the tomato occurred 2 weeks after transplant and at matured stage before flowering and after flowering. This information covers all the result of the vegetative growth including the treated samples. However, there was no record of nematodes, instead; Fusarium wilt and high salt content (toxicity) in the fresh sms probably was the cause for wilting. 
Table 4. Seasonal Support of Industrial Fertilizer (NPK) in the Vegetative Growth of Tomato

\begin{tabular}{|c|c|c|c|}
\hline Season & $\begin{array}{l}\text { Methods of } \\
\text { Application }\end{array}$ & $\begin{array}{l}\text { Quantity of } \\
\text { Fertilizer applied (g) }\end{array}$ & $\begin{array}{l}\text { \% Plant } \\
\text { Survival }\end{array}$ \\
\hline & Ring & 16.2 & $93.3^{\mathrm{a}}$ \\
\hline \multirow[t]{3}{*}{ Rainy } & Fertilizer-soil blend & 16.2 & $80^{b}$ \\
\hline & Control & 0 & $86.6^{b}$ \\
\hline & Ring & 16.2 & \\
\hline \multirow[t]{2}{*}{ Dry } & Fertilizer-soil blend & 16.2 & \\
\hline & Control & 0 & $26.6^{d}$ \\
\hline
\end{tabular}

Values with same letters do not vary at 0.05 Alpha level

\section{Impact of sms on the fruit yield (by weight) of tomato}

The result of the fruit yield of tomato is shown on table 5 and fig. 3. It revealed that weathered sms gave the highest quantity of fruits in the near dry season. Application of weathered sms gave the highest quantity of fruits in the near dry season. Application of weathered sms $(100 \mathrm{~g})$ by top dressing, produced 103 fruits weighing $1.15 \mathrm{~kg}, 50 \mathrm{~kg}$ gave rise to 54 fruits at $2,862 \mathrm{~kg}$. It was observed that fruiting continued up to 4 times before the plants senescenced and died.

The result also showed that blending or mixing weathered sms with non-acidic soil enhanced the yield of the tomato. A blend with $100 \mathrm{~g} \mathrm{sms}$ gave rise to 22 fruits weighing $229 \mathrm{~g}$, 50 produced 38 fruits, $398 \mathrm{~g}$ and $30 \mathrm{~g}$ sms blend gave rise to 46 fruits weighing $431 \mathrm{~g}$. This showed that $30 \mathrm{~g}$ sms was more efficient and tolerable by the plant. Total yields of sms soil blend were 106 fruits at $1.063 \mathrm{~kg}$ in the rainy season while the $0 \mathrm{~g}$ produced 41 fruits that weighed 521g. The ring and sms soil incorporation showed poor yield. However, during the dry season, all the treatments gave rise to poor yield except the top dressing method with weathered sms (Table 5) 
Article DOI: 10.46654/ij.24889849.e671

Table 5. Impact of Weathered SMS in the Fruiting of Remota Tomato

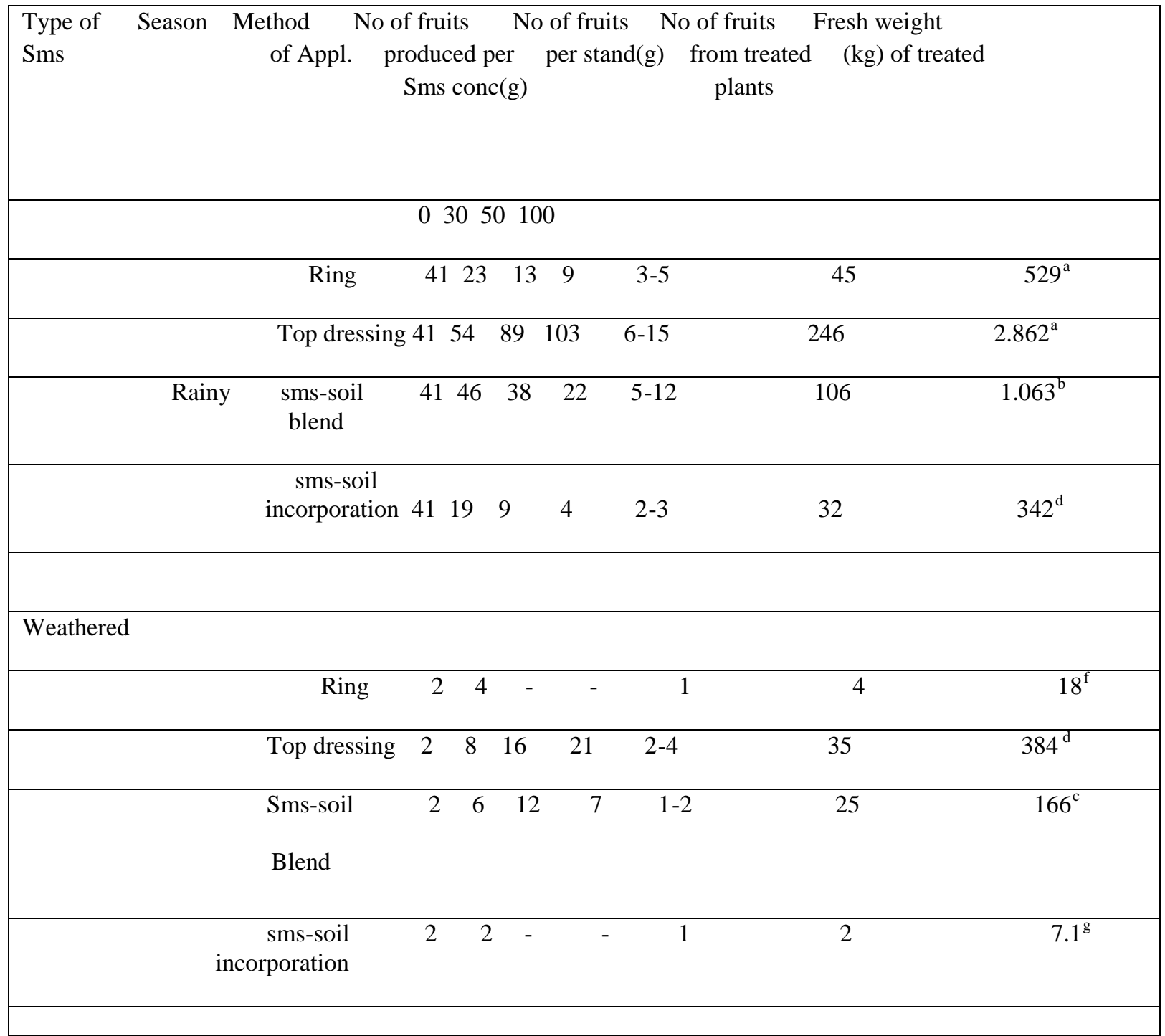

Fresh weights bearing same letters do not differ

\section{Effect of NPK on the fruit yield of tomato}

Result is shown on table 6 and Fig. 4. Application of chemical fertilizer yielded 160 fruits, weighing $2.440 \mathrm{~kg}$. Fruit sizes were big and few fruits. Fruiting lasted for only one time harvest before the plant senenscenced and died. In dry season, only 23 fruits weighing $104 \mathrm{~g}$ were harvested. In the rainy season, the biggest size of tomato was harvested, weighing $16.6 \mathrm{~g}$ (Table $6)$. 
Table 6. Effect of Fertilizer Application in the Fruiting of Tomato

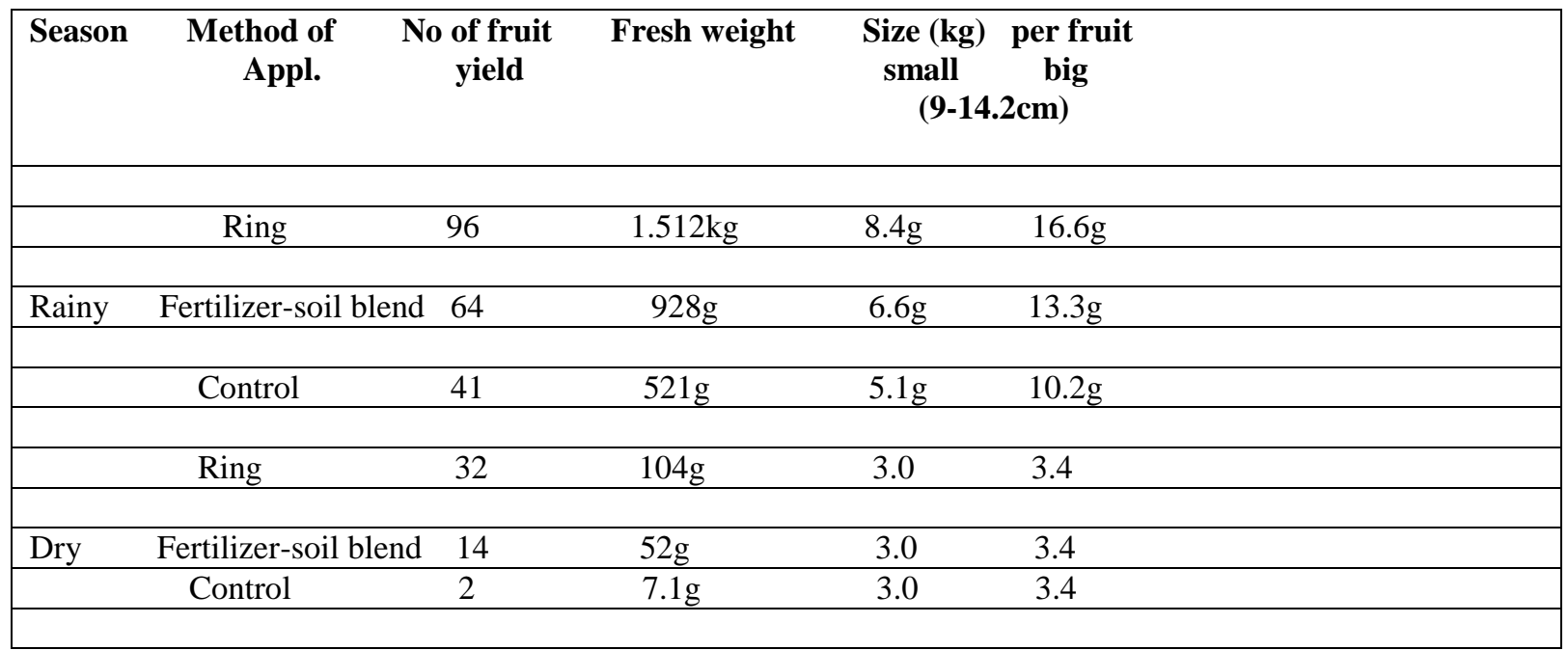

Data authenticated by Descriptive Analysis

\section{Discussion}

The result of this study indicated that SMS potting soil in nursery trials was the best method. This may be due to the composition of the SMS which made water binding possible, giving room for aeration and porosity. This may have given way for a quick germination of the tomato seeds. This is in line with the report of Dann (1996) that SMS helps soil to retain moisture in dry season and sheds it in the wet season. The gradual release of mineral nutrients in SMS might have enhanced the luxurious and vigorous growth of the tomato compared with other treatments. This agrees with the findings of Zhang et al. (1995). Application of SMS in the field revealed that fresh SMS seemed to be toxic and harsh to the tomato plant, irrespective of method of application. It is possible that the high salt content of the fresh SMS was injurious to the young tomato plants. This is in line with the reports of Romaine and Holcomb (2001) and Havgreen and Bowyer (1989) who noted that garden crops or vegetables are sensitive to high salt which could be injurious to plants. It could well mean that toxicity was as a result of ammonia nitrogen which had not undergone microbial conversion by composting to nitrates, according to Chonver et al. (2001). It may also be because the fresh SMS which had not been decomposed could not bind sufficient water, as such produced undesirable porosity.

The study further suggests that, it is the likely reason why top-dressing with weathered SMS proved to be the best method and fertilizer of the crop during the growth trials. It was obvious that beds of the tomato crop applied with SMS were weed free. This is because of extensive composting and pasteurization which possibly could not allow weed seeds to enter the SMS product. This is in line with the report from Spent Mushroom Substrate (2006).

The ability of SMS to sustain the fruiting of the tomato var. Remota for several flushes of harvest was the initial interest of this study and it has proved to be of benefit better than the performance of NPK and we can rightly recommend SMS especially the weathered to small scale farmers as organic fertilizer. 


\section{Conclusion}

This study examined the performance of spent mushroom substrate of $\underline{L}$. Squarrossulus and how it could outshine the elaborate use of field inventory for growing the Remota variety of tomato. The findings here shows that weathered sms in pot soil is better than ordinary soil and application of chemical fertilizers for nursery trials, due to its aeration porosity and water holding capacity for early seed germination. Several test trials in this study proved that the use of weathered sms by top dressing for this plant variety is the best, especially in the rainy season, as it retains water to sustain the crop. It is therefore recommended against the elaborate use of chemical fertilizer which residues pollute the ecosystem and harm the plant and man.

The successful fruiting of this agricultural variety of tomato has indeed nullified the agelong claim that agricultural varieties of tomato do not thrive in the southern Niger Delta of Nigeria where this study was conducted successfully. Conclusively, all the results have shown that the use of sms as organic fertilizer is indeed better than the use of NPK chemical fertilizers which has chemical residues on the plant and hazardous to the plant, man and the ecosystem. 


\section{References}

Ahlawat, O., Sagar, M. (2008). Management of Spent MushroomSubstrate. National Research Centre for Mushroom (ICAR). Technical Bulletin., 1-14.

Beyer, M. (1996). The impact of the mushroom industry on the environment. Mushroom News., 44 (11): 6 -13.

Beyer, D. (1999). Spent Mushroom Substrate Fact Sheet. http:/mushroom spawn.cas.psu.edu/spent.htm.

Chorover, J., Kretzschmar, R., Garcia-Pichel, F., Sparks, D. (2001). Soil Biogeochemical Processes within the Critical Zone. Elements., 3: 321-326

Dann, M. (1996). The many uses of spent-mushroom substrate. Mushroom News., 44 (8): 24-27.

Djaja, W., Suwardi, N., Dan, L., Salman, L. (2003). Research Report: Effect Of Ratio of Milk Cow Dung And Sawdust On Compost Quality: Faculty of Husbandary, Padjaran, University, Bandung., p6

Davis, D., Kuhns, L. (2005). Spent Mushroom Compost Suppress Artillery Fungi in landscape mulch in: Spent mushroom substrate. Scientific Research and Practical Applications., 5: $10-11$.

Fasidi, I., Kadiri, M., Jonathan, S., Adenikpekun, C., Kuforji, O. (2008). Cultivation of Edible Tropical Mushroom: University press, Nigeria., pp $1-8$.

Fox, R. and Chorover, J. (1999). Seeking a cash crop in spent substrate. http:aginfo.psu.edu/psa/sgg/mushroom./html

Grabbe, K. (1982). Prinzipien des Mikrobiellen Stoffum Satzesbieder Aufbereitung Flussinger and Fester. Reststoffe., 8: 237-241

Gumus, I., Seker, C. (2007). Effects of spent mushroom compost application on the physicochemical properties of a degraded soil. Solid earth., 8: 217-223

Haygreen, J., Bowyer, J. (1989). Forest products and wood science: Tud ed. Lowa state university press., p. 500.

Mahar, M. (1991). The use of spent mushroom substrate (sms) as an organic manure and plant substrate component. Compost science utilization., 2: 37-44. 
Nmom, F., Elenwo, E. (2012). Using spent mushroom substrate (SMS) as organic fertilizer in cropping Solanum lycopersicum var. remota. Nigerian Journal of Mycology., 4: 1-10

Parkinson, J., and Quarnby, C. (2000). Chemical analysis of ecological materials: Blackwell scientific publications, Oxford, London, Edinburgh, Melbourne., pp. 10-241.

Priadi, D., Saskiawan, I. (2008). The utilization of spent oyster mushroom substrates into compost and its effect on the growth of Indian mustard (Brassica Juncea (L) (Zearn) in the screenhouse. Intl. J of Agricultural Technology., 14(3): 357 - 362.

Romaine, C., Holcomb, E. (2001). Spent mushroom substrate: a novel multifunctional Constituent of potting medium for plants. Mushroom News., 49: 4-15.

Spent mushroom substrate (SMS) (2006). Brochure. Pddf spent mushroom substrate scientific research and practical applications.

http://www.americanmushroom.org/sms\%20.31st January, 2020

(Assessment).

Speranzini, D. (2007). Spent Mushroom substrate queens, printer for outario. http:iiwww.omafra.gov.on.caleEnglish/crops/hort/news/vegnews/2007/vg110792 htm.PPT 2.

Wuest, P., Fahy, H., Faling, J. (1995). Use of spent mushroom compost for maize production and its effect on surface water quality compost. Science and utilization., $3(1): 46-54$.

Zhang, W., Han, Y., Dick, W., Davis, K., Hotink, H. (1995). Compost water extract induced systemic acquired resistance in cucumber Arabidopsis. Physiopathology, 88: $450-455$. 